\title{
PENERAPAN PERPUSTAKAAN INTERAKTIF TERHADAP GENERASI MILENIAL INDONESIA
}

\author{
William Winata ${ }^{1)}$, Stephanus Huwae ${ }^{2)}$ \\ 1)Program Studi S1 Arsitektur, Fakultas Teknik, Universitas Tarumanagara, williamwinata97@yahoo.com \\ 2) Program Studi S1 Arsitektur, Fakultas Teknik, Universitas Tarumanagara, ituuuuut@yahoo.com
}

\begin{abstract}
Abstrak
Membaca merupakan sebuah proses mengamati untuk mendapatkan sebuah informasi baik dalam media literasi. Kalangan milenial Indonesia sangat bosan dan jenuh dengan kumpulan literasi-literasi sehingga mereka malas membaca. Seperti diketahui, Indonesia mendapati peringkat 1/69 dengan minat baca rendah. Hal ini diperkuat dengan 1/1.000 orang yang sangat suka membaca. Walaupun media buku digital semakin berkembang tidak membuat mereka semangat untuk membaca. Oleh karena itu bagaimana solusi dari arsitektur yang dapat memberi stimulan bagi para kalangan milenial supaya meningkatkan semangat membaca. Pendekatan melalui program yang interaktif serta menenangkan sangat dibutuhkan untuk menunjang kebutuhan informasi para kalangan milenial. Tidak hanya berfokus pada sebuah literasi belaka, namun kebutuhan informasi bisa dengan pendekatan multimedia, maupun bisa saling berdiskusi antar pengunjung untuk bisa saling berbagi informasi. Lokasi perancangan yang terletak di kawasan Pesing, Daan Mogot, Jakarta Barat ini juga menggunakan pendekatan metode desain berbasis Cellular Automata (CA) sebagai representasi dari pertumbuhan dan perkembangan buku digital.
\end{abstract}

Kata kunci: milenial; membaca; program; interaktif; multimedia

\begin{abstract}
Reading is an observational process that is utilized to acquire informations in media literatures. Millennials in Indonesia are stultified of the collected literatures that they cease to pursue reading activities. It is known that Indonesia is placed 1/69 with low reading interest. This is supported by the data that only 1 / 1,000 people actually enjoy reading. But the growing media of digital books did not generate an increase in interests. So what is the architectural response that will be able to provide stimulis for users to spark an interest in reading. Interactive and easing programs are needed to assist information necessities among millennials. Sharing informations does have have to rely on mere literature exclusively, multimedia approaches and occuring discussions between visitors can also be equally effective. The design that is located in the Pesing area, Daan Mogot, West Jakarta will apply Cellular Automata (CA) based design methods as a representation of the growth and development of digital books.
\end{abstract}

Keyword: millenial; reading; program; interactive; multimedia

\section{PENDAHULUAN}

Baca pada hakikatnya merupakan proses mengamati secara visual untuk mendapatkan sebuah informasi baik secara tertulis maupun tidak tertulis. Seperti yang diketahui minat membaca dikalangan milenial Indonesia sangat terpuruk. Bagaimana tidak, menurut hasil studi "Most Littered Nation in the World" oleh Central Connecticut State University tahun 2016, negara kita menduduki peringkat 60 dari 61 negara dengan hal minat baca dan mendapatkan peringkat akhir di ASEAN setelah Malaysia (53) dan Thailand (59). Berdasarkan data dari UNESCO tahun 2014, hanya 1 dari 1000 orang Indonesia (nilai indeks 0,01\%) yang memiliki minat tinggi dalam membaca dibandingkan dengan negara maju seperti negara Eropa-Amerika yang memiliki minat membaca sebanyak 25-27\% per tahun. Dan yang lebih menyedihkan, pertumbuhan minat baca dari tahun ke tahun mengalami penurunan dari 1,25\% hingga 4,5\%.

$\mathrm{Hal}$ ini diperkuat oleh penelitian yang dilakukan oleh Perpustakaan Nasional (PERPUSNAS) tahun 2017 lalu, yang menyebutkan jika rata-rata masyarakat Indonesia hanya membaca buku 3-4 kali per minggu dengan durasi waktu membaca per hari rata-rata 30-59 menit. Sedangkan jumlah buku yang ditamatkan per tahun rata-rata hanya 5-9 buku. Menurut data Kementerian Pendidikan dan 
Kebudayaan, sebanyak 90,27\% masyarakat Indonesia lebih suka menonton TV, dibandingkan $18,94 \%$ yang suka membaca. Dalam 1 minggu masyarakat Indonesia menghabiskan 49 jam tidur, 24 jam menonton TV, 21 jam pakai smartphone, dan 6 jam membaca, atau dalam 1 hari menghabiskan 7 jam tidur, 3,4 jam menonton tv, 3 jam pakai smartphone, dan hanya 0,8 jam atau 48 menit digunakan untuk membaca.

Ada beberapa faktor yang membuat kalangan milenial ini memiliki minat baca yang rendah, yaitu budaya yang tertanam di dalam diri sendiri dan lingkungan sekitar. Para orang tua tidak memberi platform membaca yang kuat kepada anak mereka sejak dini sehingga saat menginjak usia muda mereka enggan untuk memegang buku, bahkan membaca. Lingkungan pertemanan yang menganggap kelompok yang gemar membaca buku seperti "kutu buku, orang pintar, tidak gaul, dan sebagainya" bahkan dibully sehingga mereka menjadi malu untuk membaca buku. Kemudian banyak buku yang terlalu dikomersilkan sehingga mereka sangat malas untuk melihat sebuah buku.

Walau banyak platform yang membuat buku menjadi serba online dan bisa dibaca dimana saja, cenderung tidak membuat minat baca seseorang menjadi meningkat karena mindset atau budaya mereka akan malas membaca yang sudah tertanam sejak lahir. Mereka sangat bosan untuk melihat sebuah konten yang banyak tulisan, atau membaca disaat perlu saja. Perlu program yang bisa menstimulan mereka untuk mengubah mindset supaya dapat minat membaca. Program tersebut harus bisa membuat sebuah cover dari buku digital supaya dapat memberikan sebuah experience bagi para milenial, yaitu perpustakaan. Namun timbul sebuah pertanyaan, perpustakaan seperti apa yang cocok dan relevan untuk milenial.

Dengan adanya perpustakaan ini, membaca tidak hanya berpacu pada sebuah literasi saja, melainkan bisa dalam bentuk multimedia atau berbasis praktikal tanpa menghilangkan tujuan itu sendiri, yaitu mendapatkan informasi. Perpustakaan ini juga tidak hanya sekedar membaca, namun mengkolaborasikan dengan unsur sosial, sebagai aspek pendekatan proyek tersebut. Sehingga membaca bukan lagi sebuah momok yang serius, kaku, dan monoton, namun membaca menjadi lebih humble, fleksibel dan menyenangkan.

\section{KAJIAN LITERATUR}

\section{Perpustakaan}

Ada beberapa definisi dari perpustakaan, yaitu:

- Perpustakaan adalah mencakup suatu ruangan, bagian dari gedung / bangunan atau gedung tersendiri yang berisi buku-buku koleksi, yang diatur dan disusun demikian rupa, sehingga mudah untuk dicari dan dipergunakan apabila sewaktu-waktu diperlukan oleh pembaca (Sutarno NS, 2006:11).

- Perpustakaan adalah kumpulan atau bangunan fisik sebagai tempat buku dikumpulkan dan disusun menurut sistem tertentu atau keperluan pemakai (Lasa, 2007:12).

Bisa disimpulkan bahwa perpustakaan adalah sarana yang berupa penyimpanan buku koleksi yang bertujuan memberikan informasi kepada pengunjung dalam sarana edukatif serta membantu pendidik dalam proses kegiatan belajar mengajar.

Menurut Sutarno NS (2006:37) jenis-jenis perpustakaan adalah sebagai berikut:

- Perpustakaan Nasional RI

Merupakan Perpustakaan Nasioal yang berkedudukan di Ibu Kota Negara Indonesia yang mempunyai jangkauan dan ruang lingkup secara Nasional dan merupakan salah satu Lembaga Pemerintah Non Departemen (LPND) yang bertanggung jawab kepada Presiden.

- Badan Perpustakaan Daerah

Badan perpustakaan daerah atau lembaga lain yang sejenis adalah yang berkedudukan di tiap provinsi di Indonesia yang mengelola perpustakaan.

- Perpustakaan Umum

Perpustakaan umum diibaratkan sebagai Universitas Rakyat atau Universitas Masyarakat, maksudnya adalah bahwa perpustakaan umum merupakan lembaga pendidikan bagi masyarakat umum. 


\section{- Perpustakaan Perguruan Tinggi}

Perpustakaan yang berada di Perguruan Tinggi, baik berbentuk Universitas, Akademi, Sekolah Tinggi, ataupun Institut. Keberadaan, tugas dan fungsi perpustakaan tersebut adalah dalam rangka melaksanakan Tri Dharma Perguruan Tinggi, meliputi pendidikan, penelitian / riset dan pengabdian kepada masyarakat.

- Perpustakaan Sekolah

Perpustakaan sekolah berada di sekolah, dikelola sekolah, dan berfungsi untuk sarana kegiatan belajar mengajar, penelitian sederhana, menyediakan bahan bacaan, dan tempat rekreasi.

- Perpustakaan Khusus

Perpustakaan khusus berada pada lembaga-lembaga pemerintahan dan swasta. Perpustakaan tersebut diadakan sebagai sumber informasi dan ilmu pengetahuan yang berkaitan baik langsung maupun tidak langsung dengan instansi induknya.

- Perpustakaan Lembaga Keagamaan

Merupakan perpustakaan yang dimiliki dan dikelola oleh lembaga-lembaga keagamaan, misalnya perpustakaan, masjid, gereja.

- Perpustakaan Internasional

Perpustakaan Internasional Merupakan perpustakaan internasional yang memiliki koleksi yang menyangkut negara-negara anggota atau negara-negara yang berafiliasi kepada lembaga dunia tersebut. Perpustakaan ini dikelola dan diselenggarakan lembaga internasional.

- Perpustakaan Kantor Perwakilan Negara-negara Asing

Merupakan perpustakaan yang dimiliki dan diselenggarakan oleh lembaga / kantor perwakilan negara masing-masing. Contohnya perpustakaan lembaga kebudayaan amerika dan pusat kebudayaan jepang

- Perpustakaan Pribadi / Keluarga

Merupakan perpustakaan yang dimiliki dan dikelola oleh perorangan atau orang-orang tertentu bersama anggota keluarganya.

- Perpustakaan Digital

Perpustakaan digital bukan merupakan salah satu jenis perpustakaan yang berdiri sendiri, tetapi merupakan pengembangan dalam sistem pengelolaan dan layanan perpustakaan.

\section{Digital Library}

Digital Library (perpustakaan digital) pada dasarnya merupakan sumber daya yang merekonstruksi substansi intelektual dan layanan perpustakaan tradisional dalam bentuk suatu digital. Perpustakaan digital terdiri dari konten digital (tidak selalu berbasis teks), interkoneksi (berupa tautan sederhana atau metadata kompleks, atau hubungan berbasis permintaan), dan software (HTML atau sistem manajemen basis data yang kompleks) ${ }^{1}$.

Menurut Association of Research Libraries (ARL), 1995, mendefinisikan perpustakaan digital sebagai berikut:

- Perpustakaan digital bukanlah kesatuan tunggal.

- Perpustakaan digital memerlukan teknologi untuk dapat menghubungkan ke berbagai sumberdaya.

- Hubungan antara berbagai perpustakaan digital dan layanan informasi bagi pemakai bersifat transparan.

- Akses universal terhadap perpustakaan digital dan layanan informasi merupakan suatu tujuan.

- Koleksi-koleksi perpustakaan digital tidak terbatas pada wakil dokumen; koleksi meluas sampai artefak digital yang tidak dapat diwakili atau didistribusikan dalam format tercetak. 
Tujuan perpustakaan digital menurut Association of Research Libraries (ARL), 1995, adalah sebagai berikut:

- Untuk melancarkan pengembangan yang sistematis tentang cara mengumpulkan, menyimpan, dan mengorganisasi informasi dan pengetahuan dalam format digital.

- Untuk mengembangkan pengiriman informasi yang hemat dan efisien di semua sektor.

- Untuk mendorong upaya kerjasama yang sangat mempengaruhi investasi pada sumbersumber penelitian dan jaringan komunikasi.

- Untuk memperkuat komunikasi dan kerjasama dalam penelitian, perdagangan, pemerintah, dan lingkungan pendidikan.

- Untuk mengadakan peran kepemimpinan internasional pada generasi berikutnya dan penyebaran pengetahuan ke dalam wilayah strategis yang penting.

- Untuk memperbesar kesempatan belajar sepanjang hayat.

\section{Proses Penggunaan Perpustakaan Digital Potensi dan Pengaruh nya terhadap Generasi Milenial}

Berdasarkan sumber dari "The Millenial Library Managers: A Quick Look at Their Personality, Expectations, Beliefs and Working Style" oleh Fe Angela tahun 2014 mengatakan bahwa ada beberapa karakter pemustaka milenial yaitu:

- Terdiri dari latarbelakang yang berbeda, dan lebih mengerti secara teknik dibanding generasi sebelumnya.

- Dapat bekerja lebih fleksibel di area perpustakaan (tidak selalu kaku).

- Cenderung memiliki pemikiran yang terbuka dan bebas.

- Mudah bosan dan cenderung kreatif (dalam hal revolusioner).

Generasi milenial memiliki karakter umum yang cenderung ingin praktis. Mereka selalu ingin mencari jalan untuk mendapatkan hal yang mudah. Hal ini terkait dengan hasil kuesioner tentang kondisi sistem perpustakaan yang sebagian besar cenderung manual, seperti mencari sebuah buku yang sangat sulit dan merepotkan, terlebih buku tersebut berada di area yang teracak. Mereka merasa mencari buku seperti itu membuang waktu dan menghilangkan semangat untuk pergi ke perpustakaan. Oleh karena itu, sebagian generasi milenial mengatakan sistem digital sudah saatnya diterapkan oleh perpustakaan saat ini, dengan digitalisasi sistem dan koleksi buku. Berdasarkan hasil wawancara oleh salah satu pengurus di Perpustakaan Nasional Republik Indonesia, cara untuk mengajak pengunjung milenial Indonesia untuk pergi ke perpustakaan dengan notabene "minat baca yang masih rendah" memang menyulitkan. Berbeda dengan kondisi masih balita yang dapat membangun budaya membaca yang lebih mudah. Salah satu cara adalah dengan menstimulan para generasi milenial sesuai dengan tren mereka agar mereka dapat membaca dengan nyaman dan menyenangkan. Ini dapat memberikan stigma bahwa yang sebelumnya "membaca" memiliki momok yang serius, menjadi momok yang menyenangkan dan mengasikkan.

Walaupun e-book bisa dibaca di rumah, perpustakaan juga bisa dijadikan sebuah pusat interaktif antar-kalangan milenial. Hal ini juga diperkuat oleh sebuah survei yang dilakukan oleh Pew Research Center tahun 2016, ada 4 hal yang mempengaruhi generasi milenial untuk berkunjung ke perpustakaan, yaitu:

\section{- Adanya koneksi komputer dan internet}

Perpustakaan harus bisa memberikan suasana yang tenang dan mendapatkan akses Wi-Fi dapat membuat generasi milenial untuk semakin betah untuk masuk ke perpustakaan. Generasi milenial cenderung mengalami kesulitan ketika tanpa menggunakan Wi-Fi.

\section{- Adanya ruang seperti ruang pertemuan}

Adanya ruang pertemuan gratis dalam perpustakaan menjadi penting dan nyaman untuk para generasi milenial, khususnya untuk pekerja lepas dan pemilik usaha kecil. Mereka 
dapat menggunakan ruang tersebut untuk keperluan keperluan bisnis dan sebagainya. Mahasiswa juga merasa perlu adanya ruang tersebut sebagai ruang diskusi pembelajaran.

\section{- Adanya sebuah teknologi}

Banyak generasi milenial yang menciptakan suatu komunitas baru, khususnya dalam hal membaca. Pendekatan teknologi menjadi suatu metode baru dalam perpustakaan sehingga mereka dapat menciptakan suatu komunitas tersendiri, dengan mengenalkannya kepada orang lain, terlebih generasi milenial yang gila akan teknologi ini.

\section{- Adanya sebuah pembaharuan buku}

Generasi milenial akan semakin tertarik apabila setiap buku yang dipamerkan di dalam perpustakaan akan berganti baru/ up to date. Buku yang tidak diperbaharui atau tidak memiliki topik yang menarik cenderung membuat mereka merasa bosan dan monoton. ${ }^{2}$

Dalam buku Libraries Designed for Users: A 21st Century Guide oleh Nolan Lushington tahun 2002 menjelaskan bahwa desainer selaku arsitek harus memulai pendekatan baru yang relatif sederhana dan mengikuti perkembangan dari abad satu hingga ke era keramahan pengguna. Bagaimana sejak dahulu perpustakaan menjadi suatu momok yang serius dan mahal nya pendidikan, masuk ke sistem klasifikasi Dewey, ruang baca, hingga ke era komputasi dan digitalisasi. Sebuah perpustakaan harus ringan dan fleksibel, menyenangkan dan mengundang, ramah lingkungan, serta mengakomodasi teknologi. Kunci utama untuk perpustakaan di era sekarang ini adalah kreativitas. Perpustakaan harus membuat pengunjung terutama milenial merasa memiliki "tujuan lain" selain hanya membaca.

\section{Focus Group Discussion}

FGD (focus group discussion) adalah sebuah metode grup diskusi yang pada umumnya terdiri dari 7-11 orang (bisa 6-10 orang) yang biasanya digunakan untuk mengumpulkan sebuah data informasi dalam penelitian. Banyaknya peserta grup dalam jumlah yang relatif kecil sangat efektif dan ideal untuk bisa setiap individu mendapat kesempatan untuk berpendapat memperoleh pandangan dari peserta kelompok lain.Biasanya FGD termasuk ke dalam teknik pengumpulan secara kualitatif. Dalam metode ini Ada beberapa kegunaan dari FGD ini yaitu:

- Untuk merancang sebuah kuesioner yang membutuhkan sebuah diskusi apakah pertanyaan dalam kuesioner sudah benar, atau memerlukan pertanyaan tambahan baru untuk ditambahkan bahkan ada pertanyaan yang tidak terpikirkan sebelumnya.

- Untuk mendiskusikan hal-hal yang lebih mendalam tentang ilmu pengetahuan. Biasanya FGD akan melakukan diskusi-diskusi yang terkait dengan ilmu pengetahuan untuk menstudi terkait istilah-istilah baru dan juga penafsiran dari masyarakat lokal.

- Untuk mengumpulkan data-data kualitatif yang terkait dengan perencanaan, pemantauan, pelaksanaan dan evaluasi pembangunan. FDG semakin banyak digunakan dalam metode kualitatif dalam pembangunan dengan tujuan pemberdayaan masyarakat.

\section{METODE}

\section{Metode Penelitian}

Penulis menggunakan metode penelitian bersifat kualitatif yang terdiri dari:

- Studi Fenomenologi

Jenis penelitian ini digunakan oleh peneliti yang ingin menyelidiki sebuah fenomena dari perspektif individu atau beberapa individu yang mengalaminya. Desain penelitian ini berasal dari studi filsafat dan psikologi, sering pula digunakan dalam studi-studi sosiologi. Studi ini akan digunakan untuk meneliti program perpustakaan apa yang cocok dan relevan yang berhubungan dengan generasi milenial Indonesia saat ini.

\section{- Studi Observasi}


Metode ini merupakan metode yang menggunakan kelima indera peneliti untuk mengamati langsung di lapangan. Dalam metode ini dilakukan kunjungan ke perpustakaan nasional Republik Indonesia untuk mengamati bagaimana perkembangan perpustakaan digital terhadap generasi milenial saat ini.

\section{- Wawancara}

Metode wawancara merupakan proses memperoleh keterangan untuk tujuan penelitian dengan cara tanya jawab sambil bertatap muka antara si peneliti dengan objek penelitian. Dalam metode ini, diwawancarai seorang mahasiswa dari Fakultas Psikologi Universitas Tarumanagara dan pengurus dari PERPUSNAS mengenai pengaruh minat baca pada kalangan milenial Indonesia yang sangat rendah.

Sedangkan metode penelitian yang bersifat kuantitatif yang terdiri dari:

\section{- Metode Kuesioner}

Metode Kuesioner pada dasarnya adalah teknik pengumpulan data yang dilakukan dengan cara memberikan seperangkat pertanyaan atau pernyataan kepada orang lain yang dijadikan responden untuk dijawabnya. Metode ini digunakan untuk melihat seberapa relevansi generasi milenial terhadap perpustakaan yang juga menyebabkan minat baca mereka menjadi turun. Kuesioner ini dibagi dengan menggunakan google form dengan tersebar di provinsi DKI Jakarta yang ditargetkan kepada mahasiswa-mahasiwa di DKI Jakarta.

\section{Metode Desain}

Metode perancangan pada bangunan ini melakukan pendekatan cellular automata. Konsep ini ditemukan pada tahun 1940 oleh Stanislaw Ulam dan John von Newmann Metode ini merupakan metode dinamika diskrit dimana ruang dibagi kedalam bentuk spasial sel teratur dan waktu berproses pada setiap tahapan yang berbeda. Setiap sel pada sistem ini memiliki satu kondisi, dimana kondisi ini akan selalu update mengikuti aturan lokal, waktu yang diberikan, keadaanya sendiri, dan keadaan tetangganya pada saat sebelumnya (Wolfram, 1984).

Metode CA ini sebenarnya erat kaitannya dengan ilmu Informasi teknologi, namun diterapkan ke dalam arsitektur karena representasi dari penerapan buku digital yang semakin hari semakin berkembang.
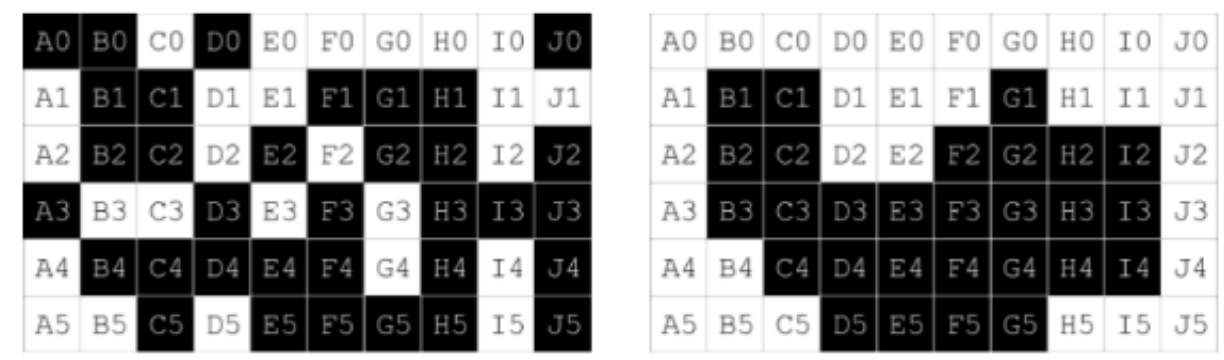

Gambar 1 : Sistem Permainan CA

Sumber :Jurnal Chaos And Geometric Order in Architecture and Design oleh Pawel R

Prinsip kerja dari metode ini adalah menentukan banyaknya grid yang akan digunakan. Kemudian pilih aturan (rule) dari permainan ini: ketika ada 1 sel hidup (hitam), maka sisa sekeliling dari sel hidup tersebut (grid $3 \times 3$ ) harus mempunyai minimum $A$ sel hidup dan $B$ sel mati. Kemudian salah satu sel hidup dari lingkungan grid $3 \times 3$ tersebut memperlakukan permainan yang sama, sehingga sel terus bertumbuh dan menyebar. Ada beberapa langkah dari pergerakan CA ini, tergantung seberapa banyak step yang dilakukan. Sel-sel hidup akan mengubah lokasi dari sebelumnya. CA akan menyubtitusi sel-sel yang mati menjadi satu kesatuan dan menciptakan komposisi arsitektur yang lebih chaos dan organik. 


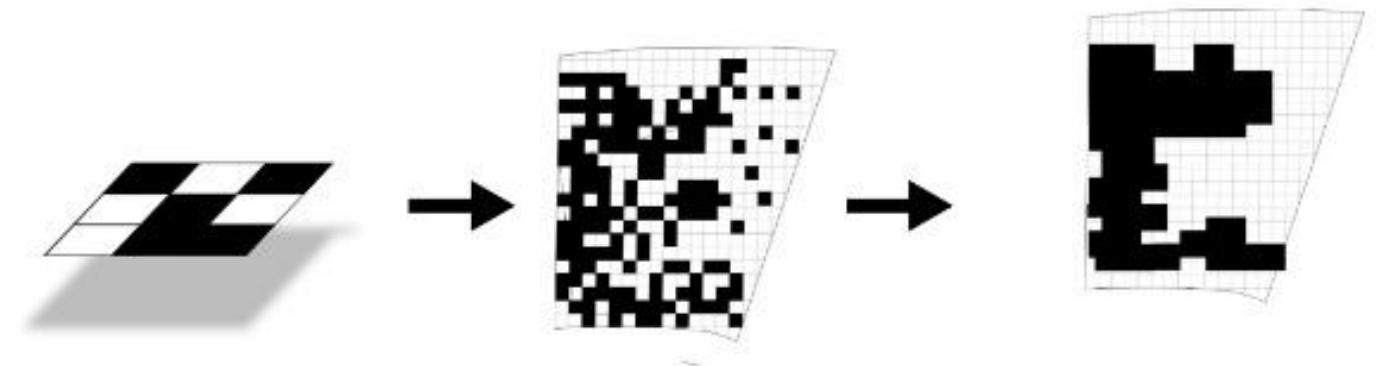

Gambar 2 : Pengaplikasian Grid terhadap Tapak Bangunan Sumber: Penulis, 2019

Penerapan metode ini pada tapak menggunakan grid dengan ukuran 2 meter $\times 2$ meter. Pendekatan ukuran ini berdasarkan standar ruang informasi yaitu dimensi ruang baca secara personal dan dimensi standar ruang pada multimedia exhibition. Grid ini akan diterapkan pada tapak dengan maksimal sepandan GSB. Aturan permainan dari CA ini adalah bagaimana dengan 1 lingkungan grid, memiliki minimal 5 sel mati dan sisanya merupakan sel hidup. Sel-sel akan terus berkembang dan merata. Kemudian step berikutnya sel-sel akan menyubtitusikan bagian sel-sel yang mati. Hingga sel-sel hidup menjadi adanya kesatuan dan terbentuk sebuah ruang-ruang yang tegas dan masif.

\section{DISKUSI DAN HASIL}

\section{Program}

Perpustakaan bukan hanya sebagai penyumbang informasi saja, namun harus ada pendekatan lain yang dapat menghidupkan aktivitas para generasi milenial ini. Perpustakaan interaktif merupakan salah satu pendekatan program yang dinilai sangat relevan dengan generasi milenial. Interaktif pada dasarnya adanya suatu komunikasi yang memiliki sifat saling berhubungan (timbal balik) antara satu aspek dengan aspek lainnya. Aspek nya bisa bermacam-macam, ada yang berbasis pengunjung-pengunjung, maupun pengunjung-media.

Bentuk ruang interaktif berupa ruang-ruang baca bersifat modular yang terdiri dari 3 jenis, yaitu modul personal, friends, dan family.

- Modul personal, yaitu ruang baca modular yang bersifat individual, dimana pengunjung akan membaca buku digital tanpa adanya intervensi dari suara luar.

- Modul friends, yaitu ruang baca modular yang memiliki kapasitas maksimal 6 orang, yang membuat pengunjung tidak hanya membaca dengan buku digital, namun bisa saling berdiskusi dengan sesama pengunjung dan mengerjakan tugas yang membutuhkan literatur dari sebuah buku.

- Modul family, yaitu ruang baca yang memiliki fungsi yang sama seperti modul friends namun memiliki kapasitas yang lebih banyak dengan maksimal sebanyak 10 orang.

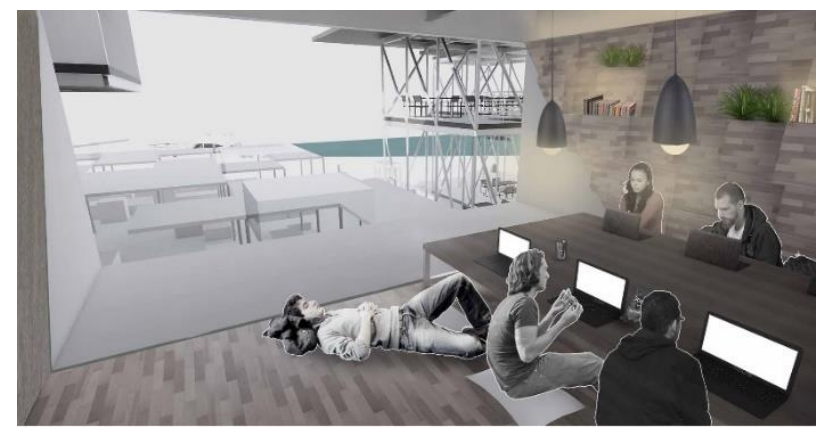

Gambar 3 : Perspektif Interior Ruang Baca Modular Tipe Families

Sumber: Penulis, 2019 
Fasilitas lain yang terdapat pada ruang baca ini adalah sebuah vending machine. Ketika pengunjung yang sudah merasa jenuh saat baca, mereka bisa makan dan minum dan berbasis makanan ringan supaya lebih mudah dibersihkan. Bentuk ruang yang didesain juga dibuat fleksibel, dengan menggunakan sejenis kursi malas yang ditaruh di lantai. Ketika saat pengunjung jenuh, bisa berbaring langsung dengan kursi tersebut. Oleh karena itu, meja disesuaikan dengan ketinggian kursi malas. Pendekatan interior pada ruang baca juga terkesan industrial dengan nuansa kayu yang nyaman dan cocok untuk generasi milenial. Dengan ini, perpustakaan akan tidak menjadi momok kaku dengan tumpukan buku yang menjenuhkan. Ada juga ruang baca yang bersifat lebih terbuka (publik), untuk pengunjung yang ingin suasana membaca lebih terbuka dan publik.

Program interaktif lainnya berupa media Virtual Reality (VR). VR sangat membantu untuk kalangan milenial Indonesia yang cenderung malas akan literasi. VR merupakan media teknologi yang membuat pengunjung merasa di lingkungan pada sebuah dunia maya yang dihubungkan dengan sebuah komputer. Media berbasis audiovisual ini mampu menarik minat generasi milenial untuk mendapatkan sebuah informasi. Hal ini juga diperkuat dengan hasil riset yang menunjukkan sekitar 90\% generasi milenial Indonesia lebih ingin melihat sebuah konten yang berbasis grafis animasi dibandingkan hanya sebatas literasi belaka. Dengan itu VR juga dapat membuat generasi milenial dapat mendapatkan pengalaman tersendiri.

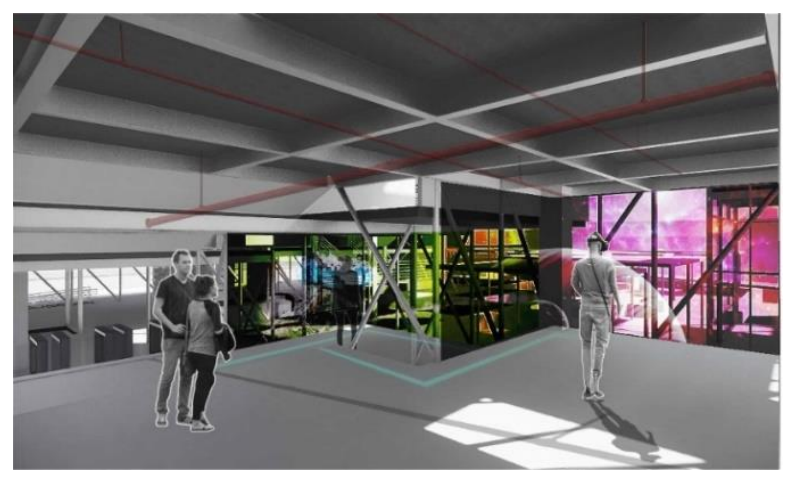

Gambar 4 : Perspektif Interior pada Ruang Multimedia Exhibition Sumber: Penulis, 2019

\section{Design Scheme dan Organisasi Ruang}
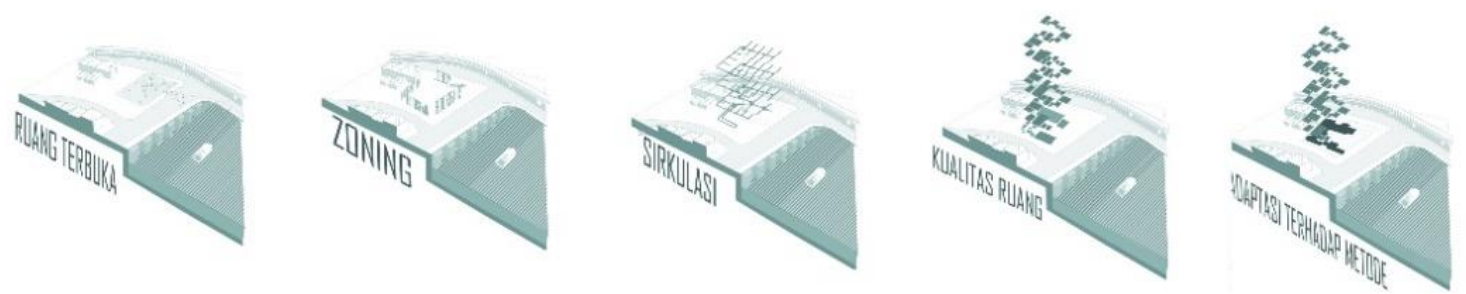

Gambar 4 : Design Scheme

Sumber: Penulis, 2019

\section{Area pusat aktivitas diletakkan berseberangan dengan riverfront}

Berdasarkan analisis bahwa konsentrasi pedestrian lebih banyak dari sisi timur (Asrama Polri dan Pasar Pesing), area pusat aktivitas dihadapkan pada sisi timur dan berhadapan dengan riverfront sebagai poin of interest. 


\section{Penentuan zoning utama}

Penentuan zona-zona berdasarkan analisis titik kebisingan,vista, analisis program sekunder, dan sebagainya terutama untuk ruang baca, bookfair, kafe.

Penentuan sirkulasi sesuai program

Berdasarkan zoning tersebut, menentukan konsep-konsep sirkulasi yang ditawarkan berdasarkan teori Edward $\mathrm{T}$ White, seperti sirkulasi bercabang, sirkulasi menerus, dan sebagainya.

\section{Penentuan kualitas ruang}

Kualitas ruang terbentuk dari sirkulasi dan sesuai kebutuhan program, apakah memiliki ruang yang berbilik, atau ruang yang memiliki skala besar, dan sebagainya.

\section{Entrance bangunan}

Entrance bangunan untuk kendaraan-kendaraan pribadi dihadapkan terhadap konsentrasi lalu lintas yang tinggi (sisi utara), dan pedestrian dihadapkan pada riverfront (sisi timur).

\section{Adaptatif terhadap metode}

Kualitas ruang diadaptasi kembali dengan proses akhir metode perancangan sehingga ruang menjadi lebih tersegmen.

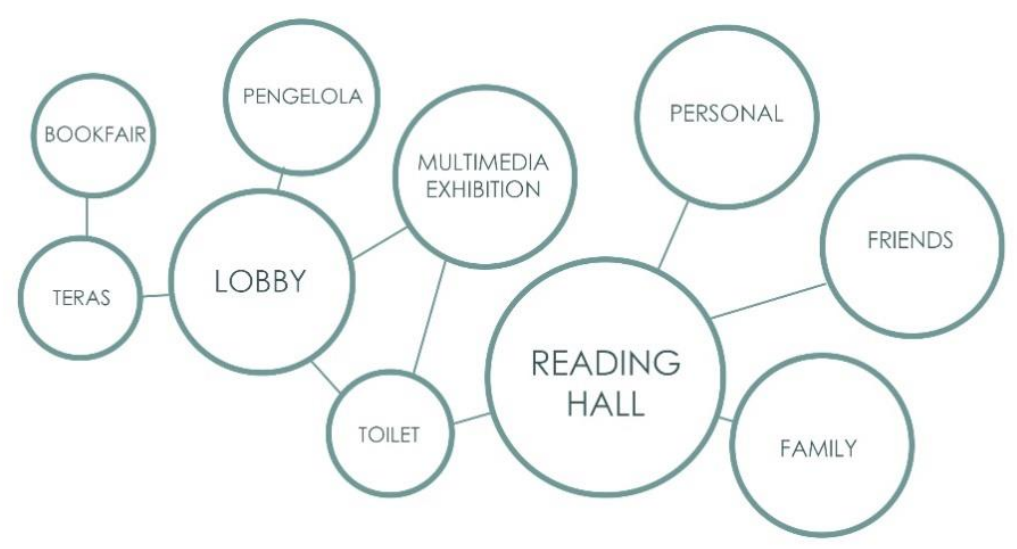

Gambar 5 : Organisasi Ruang

Sumber: Penulis, 2019

Dari keseluruhan bangunan, lobby (penerimaan) merupakan pusat dari hubungan ruang, dimana dari ruang ini akan bisa menuju langsung ke ruang multimedia exhibition, pengelola, hingga ke ruang reading hall. Dari reading hall akan bisa menuju ke ruang baca modular. Untuk area bookfair terintegrasi langsung dengan ruang luar. 


\section{LOKASI}
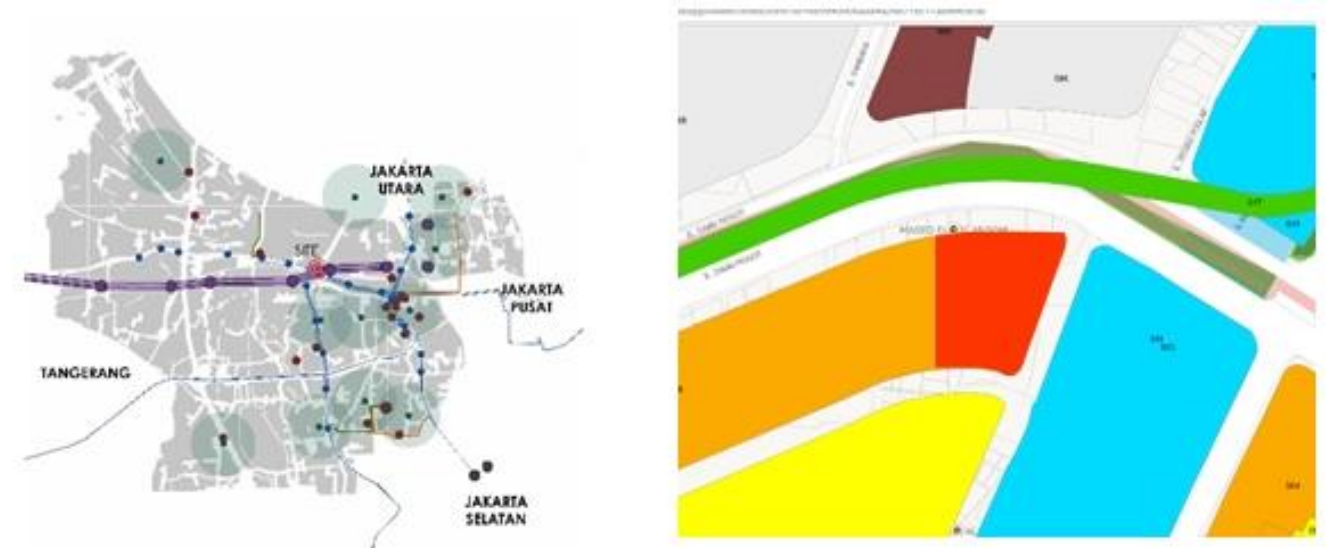

Gambar 5 : Peta Frekuensi Mobilitas Mahasiswa di DKI Jakarta dan Peruntukan Sumber: Penulis, 2019

Lokasi penempatan perpustakaan interaktif ini adalah di Jalan Daan Mogot Raya, kawasan Pesing, Jakarta Barat. Penempatan di kawasan tersebut berdasarkan frekuensi mobilitas mahasiswa untuk pergi dan pulang kuliah tertinggi. Berdasarkan hasil analisis dari kuesioner, Sepanjang jalan Panjang hingga kawasan Grogol (Sekitar Mall Central Park-Taman Anggrek) merupakan yang tertinggi. Daerah Daan Mogot yang memiliki memiliki banyak fasilitas seperti TransJakarta, Mass Rapid Transit, Light Rapid Transit, KRL, serta ojek online yang mudah diakses tidak membuat perpustakaan ini menjadi sulit untuk dicapai. Berdasarkan tahun 2030 proyeksi sistem peruntukan DKI Jakarta, kawasan Pesing yang cenderung memiliki zona campuran membuat kawasan ini nantinya akan berkembang seiring dengan penempatan MRT di Jalan Daan Mogot. Tapak yang terpilih juga memiliki beberapa kelebihan, salah satu nya memiliki riverfront dari sisi timur tapak. Ini bisa dijadikan sebuah potensi supaya pengunjung dapat meramaikan perpustakaan ini dengan meletakkan pintu masuk pedestrian sejajar dengan riverfront, dan zonasi bookfair juga berseberangan dengan riverfront tersebut.

\section{KESIMPULAN DAN SARAN}

Berdasarkan hasil penelitian yang dikaitkan dengan beberapa literatur, solusi untuk meningkatkan minat baca para generasi milenial Indonesia dengan perpustakaan yang memberikan esensi experience berupa program interaktif. Program interaktif tidak menjadikan sebuah media baca (buku digital) untuk mendapat informasi, melainkan diskusi sesama pengunjung serta pendekatan multimedia. Dari perpustakaan ini diharapkan dapat dijadikan contoh dalam perpustakaan-perpustakaan di Indonesia, khususnya di Jakarta supaya dapat meningkatkan minat baca para pembaca milenial.

\section{REFERENSI}

Admin. (2018). Revolusi Industri 4.0: Perpustakaan Harus Berani Bertransformasi. Retrieved February 17, 2019, 13:40, from https://www.solotrust.com/read/13227/Revolusiindustri-40-Perpustakaan-Harus-Berani-Bertransformasi

Agam, S. (2017). Gerakan Literasi Nasional! Strategi Giatkan Minat Baca! Retrieved July 2, 2019, 17:23, from http://indonesiabaik.id/infografis/gerakan-literasi-nasional-strategigiatkan-minat-baca

Angela, F. (2014). The Millenial Library Managers: A Quick Look at Their Personality, Expectations, Beliefs and Working Style. Retrieved July 2, 2019, from https://www.slideshare.net/verzosaf/the-millennial-library-managers-a-quick-look-ontheir-personality-expectations-beliefs-and-working-style 
Darmawan, H., (2018). Buka Rakornas Perpustakaan 2018 Wapres : Perpustakaan Ciptakan Manusia Berdaya Saing. Retrieved July 2, 2019, 17:15, from https://www.perpusnas.go.id/news-detail.php?lang=id\&id=180423080531RAdTIfONrG

Emanuel, J. (2011). Millennial Librarians: Who They are and How They are Different from the Rest of Us. 322-327

Geiger, A.W. (2017). Millennials are the most likely generation of Americans to use public libraries. Retrieved Januari 20, 2019, 18:36, from https://www.pewresearch.org/facttank/2017/06/21/millennials-are-the-most-likely-generation-of-americans-to-usepublic-libraries/

Hutasuhut, R. (2017). Generasi Milenial Tidak Memiliki Minat Baca? Retrieved February 10, 2019, 21:25, from https://www.kompasiana.com/ronaldhutasuhut/58e7ebeed192737e38e346af/menggali -minat-baca-masyarakat-milenial?page=all

Indrizal, E. (2014). Diskusi Kelompok Terarah Focus Group Discussion (FGD): Prinsip-Prinsip dan Langkah Pelaksanaan Lapangan. Journal Antropologi. 16(1). 75-8

Lushington, N. (2002). Libraries Designed for Users: A 21st Century Guide. Michigan: NealSchuman Publishers

Main, D. (2019). Who are the Milenials? Retrieved February 10, 2019, from https://www.livescience.com/38061-millennials-generation-y.html

Michael S., \& Elke G. (2007). Defining A Digital Library. Library High Tech. 25(2). 169-173

Miller, J. W., \& Michael, C. (2016). World Literacy: How Countries Rank and Why It Matters. Newyork: Routledge

Riadi, M. (2012). Pengertian, Jenis, dan Tujuan Perpustakaan. Retrieved January 17, 2019, 19:20, from https://www.kajianpustaka.com/2012/11/perpustakaan.html

Rubinowicz, P. (2000). Chaos And Geometric Order in Architecture and Design Journal for Geometric and Graphics. 4(2). 197-207 
